\title{
Assessment Irregularities among Academic Staff of Nigerian Universities: A Study of Students' Perceptions
}

\author{
Isaac Ofem Ubi", Bassey Asuquo Bassey, German Efa Anagbogu, Ofem Usani Joseph \\ Department of Educational Foundations, University of Calabar, Calabar, Nigeria
}

Received November 12, 2020; Revised December 31, 2020; Accepted February 17, 2021

\section{Cite This Paper in the following Citation Styles}

(a): [1] Isaac Ofem Ubi, Bassey Asuquo Bassey, German Efa Anagbogu, Ofem Usani Joseph, "Assessment Irregularities among Academic Staff of Nigerian Universities: A Study of Students' Perceptions," Universal Journal of Educational Research, Vol. 9, No. 3, pp. 461-465, 2021. DOI: 10.13189/ujer.2021.090305.

(b): Isaac Ofem Ubi, Bassey Asuquo Bassey, German Efa Anagbogu, Ofem Usani Joseph (2021).Assessment Irregularities among Academic Staff of Nigerian Universities: A Study of Students' Perceptions. Universal Journal of Educational Research, 9(3), 461-465. DOI: 10.13189/ujer.2021.090305.

Copyright $\odot 2021$ by authors, all rights reserved. Authors agree that this article remains permanently open access under the terms of the Creative Commons Attribution License 4.0 International License

\begin{abstract}
Assessment irregularities are corrupt and unethical activities introduced in determination of learner's outcome. Assessment irregularities refer to all corrupt and unethical activities introduced by teachers in determining the abilities of the learner. The study analyzed assessment irregularities among academic staff of universities in Nigeria as perceived by their students. Relevant literature to this phenomenon indicates that the Nigerian Education is plagued by irregularities ranging from examination malpractices by students to falsification of assessment of students by their teachers. The design adopted for this study was survey. The sample was made up of 450 students from two public universities (one federal owned and the other state owned) in the country. Stratified and purposive sampling techniques were used to select the sample. The instrument used for data collection was a checklist designed by the researchers and titled Assessment Irregularity Scale (AIS). Cronbach alpha reliability coefficient of the instrument was .81. Results of the study showed that students' perceived assessment irregularities among academic staff are high for most items. The results also showed that place of residence, attitude towards school and self concept influenced students' perceptions about irregularities of their lecturers. Based on the findings, it was recommended that there should be wide training of university teachers, on periodic basis, in order to equip them with testing skills and modern assessment practices.
\end{abstract}

Keywords Assessment Irregularities, Academic Staff, Students' Perception

\section{Introduction}

Assessment remains an integral part of learning due to its pivotal role in education. No serious educational activity takes place without assessment at the center of it. In fact, the rationale behind the use of assessment is to ensure educational goals are achieved and students are exposed to acquire the right knowledge and skills relevant for every day functioning in the society. As noted in [1], that assessment is a fact finding exercise that is aimed at collecting a cumulative form of information about the progress of instruction, learners' behavioral changes as well as availability of a particular trait, or characteristics, as a baseline for decision making.[2] "Assessment is a process of gathering information for the purpose of making decision. It is a conscious effort of exploring different avenue in order to gather relevant information about the progress of an instructional program, progress of the learner in a classroom setting."

The beauty of assessment practices is that it does not just end in obtaining data about the learner but serves as a mirror to the teacher, policy developers, curriculum planners and even administrators. In the classroom situation, assessment helps the teacher to a very large extent. Assessment tools and strategies differ according to setting and examining. In instructional delivery, the teacher is always conscious of the fact that given the varieties of learners in the class, different instructional methodologies are always utilized [3]. Assessment helps in decision making and also helps in determining the progress, success and failure of a particular phenomenon. 
The purpose of assessment in education is not to witch-hunt learners, but as [4]rightly put it; it is to ensure that the right students are selected, placed, guided and counselled, promoted, diagnosed, predicted among others. Most of the educational outcome in schools is a product of assessment. Therefore, from the classicalist test point of view, the determination of the true score of the examinee stems from the administration of series of same test in order to obtain the average which could be described as the true score of the examinee. Thus, anything done before, during and after assessment with the capacity to introduce systematic error is termed assessment irregularities.

\section{Literature Review}

Assessment irregularities are concerned with any activity that violates the rules of assessment. It is presence of corrupt practices in the assessment process among teachers. The concept of assessment irregularities has been defined by different researchers in different ways. Examples include: "Events which can cause assessed performance that are not related to actual performance" [2]. "Acts that involve noncompliance with the organisation's agreements, like manipulations, falsification, forgery or alterations of documents"[5]. "A deliberate act of wrongdoing, contrary to official examination rules, and is designed to place a candidate at an unfair advantage or disadvantage" [6].

Assessment irregularities, in the context of this article, refer to all activities that are carried out by teachers for the purpose of not actually determining the abilities of the learner but rather having advantage over students. It could also be described as an activity with the intension of extorting monies as well as pervading due processes in assessment. In a nutshell, assessment irregularities are the presence of corrupt and unethical activities introduced in determination of learners' outcome. However, it has been observed over the years that the level of assessment irregularities in tertiary institutions is high. An assessment irregularity does not only limit itself to bribery and corruption in the class, it concerns the use of poor assessment strategies, poor assessment instruments, abandonment of test construction principles, and assessment for punishment, among others. On the other hand, it involves the use of illegal means such as sorting, intimidation and harassment, plagiarism, etc. This state of affairs has triggered a lot of attention from researchers and measurement experts as to what probably would have been the cause of assessment irregularities among academic staff. According to [7]; [8] and [9] "lack of knowledge of assessment principles, abuse of test purposes, greed, absence of examination screening committees etc., are possible reasons for assessment irregularities". Effect of this problem is expressed in public damage of the confidence in the validity and legitimacy of graduates from our universities, wrong decision on the ability of the learner, lack of seriousness among students. Efforts made over time to address this problem have not yielded the right result. It was on this basis that the researcher is poised to carry out a study to analyze irregularities in assessment among academic staff in universities in Cross River State, Nigeria.

In a study on the perceived corrupt practices of academics in Ghana [10] disclosed that "favouritism, nepotism and examination malpractices were perceived by students as being the main elements of corruption among university teachers". Other factors revealed by the survey as promoting the act were fear of victimization, fear of school authority and bureaucracy in dealing with such issues.

Earlier studies on the comparison between irregularities and educational outcomes have reported negative relationships. The study of [1] noted that "corruption in the form of irregularities in examination and other activities within the tertiary institutions has the tendency to reduce the ethical values of students". This was replicated by[3] in their opinion that "when students realize that personal success depends not on performance but on bribery, favouritism and nepotism, then they would develop unethical behaviour, which can be passed on to the next generation." Thus, when students are aware that what is done by the teacher as assessment is only targeted at them collecting monies rather than facilitating instruction, there is every tendency that they get discouraged from taking active part in academics.

Literature available indicates that there has been more attention on students' perception of teachers' classroom assessment based on their personal characteristics rather than perception of the teachers as influenced by the students' personal characteristics. For instance, [11] found a significant relationship between students' attitude towards mathematics and their perception of teachers. An earlier study by [12] indicated that "there were no statistically significant gender difference in perceived assessment skills in analyzing test items using performance assessment and grading".

Place of residence of university students could be an important factor in determining their perception towards certain school activities. On-campus students reside in hostels provided for them by the school inside the school premises, while off-campus students are those who reside outside the school premises. Off-campus students live alone most of the time and are away from some activities and rules of the school. Interactions with lecturers, by off-campus students after lectures are limited most times. Commenting on students' satisfaction with their residential environment [13] concluded that "on-campus students have more positive perceptions about the hostel accommodation they occupy in terms of facilities like Internet Connectivity, Electricity, and Bed Space than 
off-campus students."

\section{Hypotheses}

$\mathrm{H}_{1}$ : Students' perception of assessment irregularities among academic staff of their Universities is not significantly positive.

$\mathrm{H}_{2}$ : Students' personal characteristics do not significantly influence their perception of assessment irregularities among academic staff of their Universities.

\section{Research Method}

The research area was Cross River State of Nigeria. Cross River State is one of the 36 states of the Federal Republic of Nigeria. The state is in the South-South Geo-Political Zone of the country. As at the time of this study, the area had two public universities (University of Calabar \& Cross River University of Technology). Survey research design was adopted for the study. Sample selection was done through stratified and purposive sampling techniques. The two Universities in the state were the basis of stratification. Since the two universities do not have the same number of faculties, the researchers deliberately used those faculties common in the two for the study. Selection of subjects for the survey was done by proportion resulting in choosing $10 \%$ of the population of students from each faculty. Consequently, a sample of 450 students was drawn from45,048 students, constituting the population of students in six public universities, as at the $2018 / 2019$ academic session. Those selected into the sample completed the data collection instrument titled 'Assessment Irregularity Scale (AIS).'The instrument had a reliability coefficient of 0.81 . The reliability coefficient of the instrument was obtained through a trial test on 50 students of a University outside the study area. Before the survey commenced, the researchers obtained permission from authorities of the institutions, and got participants' consents to take part in the survey. Data collected were analyzed using Population and Independent t-test statistics, and conclusions were drawn at.05 level of significance.

\section{Results}

\subsection{Hypothesis One}

Students' perception of assessment irregularities among academic staff of their Universities is not significantly positive. The variable involved in this hypothesis is perceived assessment irregularities. One-sample t-test was used in testing this hypothesis. The result as presented in Table 1 showed that the respondents agreed to all the items except item 9 and 10 whose mean is below the criterion mean of 2.50. However, the grand total obtained mean of 26.12 is greater than the grand criterion mean of 25.0. A cursory look at the table also showed that the calculated t-value of 44.2 was significant at .05 . This implies that students' overall perception of assessment irregularities among academic staff of their Universities is significantly positive. That is, the students had a positive view about irregularities in assessments by their lecturers. Based on this, the null hypothesis is rejected.

Results on the students, views concerning leakages of question papers and allowing students to write answers into their answer scripts after official time for examination did not show agreement. This implies that the students do not perceive their lecturers as involving themselves in leakage of examination questions and allowing students to update answers already given after the examination. For these two items, the null hypothesis is accepted.

Table 1. Population t-test of students' perception of assessment irregularities among academic staff of universities

\begin{tabular}{|c|c|c|c|c|c|c|c|}
\hline $\mathbf{S} / \mathbf{N}$ & ITEMS & $\mathbf{N}$ & $\mathbf{X}$ & S.D & df & t-cal & p-val \\
\hline 1 & $\begin{array}{l}\text { On the average, I think my lecturers can: } \\
\text { Administer unannounced tests }\end{array}$ & 450 & 2.92 & .914 & 449 & 67.76 & .000 \\
\hline 2 & Award assessment scores when we have not written any test & 450 & 2.84 & .903 & 449 & 66.68 & .000 \\
\hline 3 & Do not supervise us very strictly during examinations & 450 & 2.66 & .993 & 449 & 56.80 & .000 \\
\hline 4 & Do not allow us use required time for the examinations & 450 & 3.10 & .855 & 449 & 76.88 & .000 \\
\hline 5 & Do not set examinations based on what is taught & 450 & 2.78 & .107 & 449 & 58.56 & .000 \\
\hline 6 & Use ambiguous terms in setting examinations & 450 & 2.72 & .961 & 449 & 60.03 & .000 \\
\hline 7 & Allow students impersonate during examinations & 450 & 2.84 & .988 & 449 & 60.96 & .000 \\
\hline 8 & Leak questions to students before the examination is taken & 450 & 3.02 & .893 & 449 & 71.03 & .000 \\
\hline 9 & $\begin{array}{c}\text { Provide some students with answer booklets to write answers after the } \\
\text { examination }\end{array}$ & 450 & 1.40 & .981 & 449 & 1.66 & .053 \\
\hline \multirow[t]{2}{*}{10} & Accept money from students to upgrade their scores & 450 & 1.88 & .910 & 449 & 1.16 & .077 \\
\hline & Overall total & 450 & 26.10 & 1.11 & 449 & 44.23 & .000 \\
\hline
\end{tabular}


Table 2. Independent t-test analysis of the influence of some students' personal characteristics on their perceived assessment irregularities among lecturers

\begin{tabular}{|c|c|c|c|c|c|c|c|}
\hline $\mathbf{S} / \mathbf{N}$ & Variable & Category & $\mathbf{n}$ & Mean & SD & Df & $\mathbf{t}$ \\
\hline \multirow{2}{*}{1} & \multirow{2}{*}{ Gender } & Male & 225 & 26.27 & 5.17 & \multirow{2}{*}{448} & \multirow{2}{*}{0.74} \\
\hline & & Female & 225 & 26.01 & 5.10 & & \\
\hline \multirow{2}{*}{2} & \multirow{2}{*}{ Place or Residence } & On-Campus & 187 & 23.95 & 5.75 & \multirow{2}{*}{448} & \multirow{2}{*}{-9.25} \\
\hline & & Off-Campus & 263 & 28.43 & 5.62 & & \\
\hline \multirow{2}{*}{3} & \multirow{2}{*}{ Attitude Towards School } & Positive & 301 & 23.37 & 5.90 & \multirow{2}{*}{448} & \multirow{2}{*}{-14.78} \\
\hline & & Negative & 149 & 29.01 & 6.24 & & \\
\hline \multirow{2}{*}{4} & \multirow{2}{*}{ Self Concept } & Positive & 296 & 23.43 & 5.11 & \multirow{2}{*}{448} & \multirow{2}{*}{-11.83} \\
\hline & & Negative & 154 & 28.97 & 5.83 & & \\
\hline
\end{tabular}

\subsection{Hypothesis Two}

Students' personal characteristics do not significantly influence their perception of assessment irregularities among academic staff of their Universities.

The independent variable is students' personal characteristics (classified into gender, residence, place attitude towards school, and self concept), while the dependent variable is perceived assessment irregularities measured continuously. Each of the sub-independent variables was dichotomized and tested using independent t-test statistic. See Table 2 for results of the test. The results showed that the calculated t-values of $9.25,14.78$ and 11.83 for the comparisons among students' place of residence, attitude to school and self concept and their perceptions of assessment irregularities were each greater than the critical t-value of 1.96 at .05 level of significance. These results mean that place of residence; attitude to school and self concept of students influenced how they perceived assessment irregularities among their lecturers in Nigerian Universities. Off-campus students admitted more than their on-campus counterparts that their lectures were irregular in their assessments. Students with negative attitude to school and those with negative self concept perceived their lecturers as involving in assessment irregularities than their counterparts with positive perceptions. The comparison between gender and students' perceptions did not, however, yield significant influence. Based on the result, the null hypothesis regarding students' gender is accepted, while it is rejected with regards to place of residence, attitude to school, and self concept.

\section{Discussion of Findings}

The study findings on the positivity of the students' perception of assessment irregularities of their lecturers are in agreement with the study of [10] which disclosed that students' perception of corrupt practices of academics in Ghana was positive. That study identified favouritism, nepotism, and examination malpractices as the forms of irregularities perceived by the students. These forms of irregularities have contaminated the system of education in the West African region in general and Nigeria in particular. Students obtain scores that are not reflective of their true abilities in tests and examinations, and this is of great concern to researchers.
These irregularities could be due to multiple factors with the school environment and the Nigeria society. First, this could be due to the fact that most academic staff do not have adequate knowledge of the rationale for assessment in school. The philosophies establishing the activities of assessing students are not very clear to them resulting in their lack of basic skills and competencies needed in developing and validating standard assessment instruments that can be used for learner's assessment. It could also be due to the fact that most academic staff do not see assessment as a medium to facilitate instruction but rather as a tool for wit hunting students especially those they consider the lazy type. Most of them see assessment as a commodity that could be traded with and this may account for the irregularities that are found in the study. The study findings were, however, converse in some respect. It was observed that the subjects did not perceive their lecturers as providing students with answer booklets to improve responses to questions after tests and examination sessions. Similarly, the students did not perceive their lecturers as accepting gratifications for improvement of grades. The reasons for these converse opinions call for further research as they are difficult to comprehend.

Findings on the comparison between students' personal characteristics and assessment irregularities among their lecturers were to a large extent significant. Off-campus students, for instance, perceived the lecturers differently from their on-campus counterparts. The off-campus students attested more to the irregularities of their lecturers than the on-campus students. Findings on attitude towards school and self concept were in support of positivity as there seem to be a tilt towards exonerating lecturers of irregularities in assessment. That is, students with positive attitude and positive self concept were less apprehensive of the lecturers than their counterparts with negative attitude and negative self concept. The findings are in support of [11].The findings on students' gender and perception are support of [12] who, in a way, found no significant difference in the way male and female students perceived their teachers' assessment irregularities.

\section{Summary and Concluding Remarks}

This study highlighted some assessment irregularities 
feared to be indicators of corrupt practices among lecturers of Universities in Cross River State, as perceived by their students. Results of the study indicate that students perceive high levels of assessment irregularities among their lecturers. This constitutes a bane in the educational system of the state in particular and Nigeria in general. Lecturers carry out assessment of students the way they like without following basic principles governing such assessments. This may bring about anxiety before and during examinations and subsequently induce corrupt tendencies like cheating to succeed. Against this backdrop, the researchers recommend as follows:

i). Individual Universities in Cross River State should adopt uniform assessment procedure in which lecturers will be made to conduct tests and examinations following approved timetable. By this method, students will be aware of their assessment dates ahead of time.

ii). Students' scripts should be vetted after each test to discourage falsification of scores.

iii). Supervision of examinations should be organized centrally to encourage proper invigilation.

iv). School authorities should emphasize adequate time keeping during examinations, so that the students can be allowed to use complete allotted time for each examination they write.

v). Universities should encourage team teaching to ensure that lecturers cover their course outlines before examinations are given.

vi). Examination questions should be subjected, at all times, to vetting to reduce ambiguity in language use in setting them.

vii). Lecturers should be encouraged to give mid-semester tests.

viii). Universities should constitute quality assurance units in all departments to check, discover and implement sanctions formal practices by students and lecturers.

\section{REFERENCES}

[1] U. J. Ofem and S. V. Ovat. Assessment of teachers' knowledge, awareness and application of ICT in instructional delivery in secondary schools in Cross River
State, Global Journal of Educational Research, Vol. 3, No. 15, pp 145-50, 2016

[2] G. Glidden. Assessment irregularities: A discussion guide for current issues in test administration, http://www.natd.org /Gliden96.htm,1996

[3] U. J. Ofem, R.O.Ogar, and L. I. Udie. Utilization of differential assessment techniques in inclusive classrooms in tertiary institutions, In M. T. Joshua, P. N. Asuquo and J. S. Petters, (Eds.), Education for careers in the $21^{\text {st }}$ century(a Festschrift in honour of Professor Daniel I. Denga), Calabar, University of Calabar Press, 2017

[4] D. I. Denga. Educational measurement, continuous assessment and psychological testing, Calabar, Rapid Educational Publishers, 2004

[5] Information Systems Audit and Control Association (ISACA). Irregularities and illegal acts, Illinois, USA, 2005

[6] The World Bank Group. Public examination system: Topics - Malpractice,the World Bank Group, http://www.worldba nk.org.education/exams/malpractice/asp, 2001

[7] S. Friday. Challenges associated with utilizationof test construction among teachers in secondary school, Journal of Sustainable Development in Africa, Vol. 13, No. 5, pp 201-224, 2013

[8] A. Iniobong. Adherence to test principles among academic staff in universities in Akwa Ibom State, Journal of Education and Practice, Vol. 4 No. 1, pp 30-35, 2014

[9] G. Ukele. Corruption in Nigeria: A colossal legacy. Inaugural lecture.Uyo: University of Uyo Press, 2017

[10] A. Kuranchie, C. Twene, M. Mensah, and C. Arthur. Perceived corrupt practices of academics: what conditions promote them? Academic Journal of Interdisciplinary Studies, Vol. 3 No. 1, pp 12-27, 2014

[11] H. Alkharusi. Teachers' classroom assessment skills: influence of gender, subject area, grade level, teaching experience and in-service training, Journal of Turkish Science Education, Vol.8, No. 2, pp 39-48, 2011

[12] E. N. Etuk, M. E. Afangideh, and A. O. Uya. Students' perception of teachers' characteristics and their attitude towards mathematics in Oron Education Zone, Nigeria, International Education Studies, Vol. 6, No. 2, pp 197-204, 2013

[13] M. H. Muslim, H. A. Karim, I. C. Abdulla. Satisfaction of students' living environment between On-Campus and Off-Campus settings: A conceptual overview. Procedia Social and Behavioral Sciences. Vol. 68, pp 601-614, 2012. www.sciencedirect.com 